\title{
SECRETIVE SYMBOLISM? THE DEATH PENALTY, EXECUTIONS, AND JAPAN
}

\begin{abstract}
The importance of analysing the death penalty and state-imposed executions is derived from their concerning the right to life, and their retaining widespread support throughout retentionist, abolitionist de facto, and abolitionist states worldwide. Discrepancies in the execution rates of retentionist states appear reducible to their serving symbolic or pragmatic functions i.e. they are used primarily to validate public opinion or primarily to deter crime. Prima facie, Japan seems akin to a symbolic state, due to its low execution rate and its official justification for both retaining the death penalty and continuing to use executions i.e. doing otherwise would be undemocratic. However, the practices that surround executions in Japan shroud them in secrecy and silence, which appears at odds with both its apparent symbolic function and this justification. This makes Japan a uniquely important case study for research on practices surrounding executions. Understanding why this contradiction exists will entail a more nuanced understanding of the ways in which the death penalty, executions, and the practices surrounding them, can function in retentionist states. This essay aids such understanding by critically analysing this official justification and various other arguments for why this might be the case and advancing an alternative explanation.
\end{abstract}

\footnotetext{
*Billy Holmes, University of Bristol, Bristol, UK. E-mail: wh13102@my.bris-
} tol.ac.uk. 


\section{ANALYSING THE DEATH PENALTY}

The importance of analysing the death penalty is primarily derived from its concerning the "supreme right:" the right to life. ${ }^{1}$ There appears to be no government power greater than that of life and death. ${ }^{2}$ Accordingly, there seems to be "no government power in greater need of public oversight." 3 The importance of analysing the death penalty also pertains to the persistence of wide-spread public support throughout retentionist, ${ }^{4}$ abolitionist in practice (de facto) ${ }^{5}$ and abolitionist ${ }^{6}$ states worldwide. For instance, in Russia and Bra$\mathrm{zil}^{7}$ (abolitionist de facto states), 62\% and $57 \%{ }^{8}$ of the public favour reinstating capital punishment, respectively. ${ }^{9}$ Such support apparently motivated the Pilipino House of Representatives to approve a

${ }^{1}$ ECOSOC. (1949). Summary Record of the 98th meeting. New York: United Nations, 10; The Government of Japan (1948). The Constitution of Japan. http:// www.japaneselawtranslation.go.jp/law/detail_main?id=174(accessed on 18/7/2020), article 13; United Nations Human Rights Committee. (2019). General comment No. 36 Article 6: Right to life. https://tbinternet.ohchr.org/_layouts/15/treatybody external/Download.aspx?symbolno $=\mathrm{CCPR} / \mathrm{C} / \mathrm{GC} / 36 \&$ Lang $=$ en $($ accessed on 18/7/ 2020), 2.

2 Johnson, D.T. (2006a). Japan's Secretive Death Penalty Policy: Contours, Origins, Justifications, and Meanings. APLPJ, 7, 62, 76.

${ }^{3}$ Ibid.

${ }^{4}$ I.e. states that retain the death penalty.

${ }^{5}$ I.e. states that have formally retained the death penalty but have not used it in at least 10 years.

${ }^{6}$ I.e. states that have abolished the death penalty for all civilian crimes but retained it for military crimes and states that have abolished the death penalty for all civilian and all military crimes.

${ }^{7}$ For example, Brazil provides for the death penalty under exceptional circumstances i.e. during war; Amnesty International. (2018). Abolitionist and Retentionist Countries as of July 2018. https://www.amnesty.org/en/documents/act50/6665/2017/ en/ (accessed on 18/7/2020).

${ }^{8}$ This is the highest recorded level of support polled in Brazil since Datafolha started polling on this subject in 1991; Boldrini, A. (2018). Support for Death Penalty at Record Levels Among Brazilians. https:/www1.folha.uol.com.br/internacional/ en/brazil/2018/01/1949074-support-for-death-penalty-at-record-levels-among-brazi lians-datafolha-finds.shtml (accessed on 18/7/2020).

${ }^{9}$ Obrazkova, M. (2014). The ultimate sentence: Where do Russians stand on capital punishment? Russia Beyond. https://www.rbth.com/society/2014/06/11/the_ulti mate_sentence_where_do_russians_stand_on_capital_punishment_37375.html (ac cessed on 18/7/2020); Boldrini supra 8. 
bill to re-impose the death penalty on 17th March 2017. This bill is currently pending Senate approval. ${ }^{10}$

The sub-regions of East Asia and Southeast Asia are comprised of 16 of the world's 196 states. $^{11}$ Nine of the world's 56 retentionist states are located there. ${ }^{12}$ In 2016, an estimated 5,181 death sentences were handed out globally. ${ }^{13}$ At least 2457 of these $(47.42 \%)$ were handed out in these two sub-regions. ${ }^{14}$ In 2018, an estimated 4531 death sentences were handed down globally. At least 2427 of these $(53.56 \%)$ were handed out in these two sub-regions. ${ }^{15}$ Thus, these

${ }^{10}$ Panti, L. (2018). House approves death penalty bill. The Manila Times Online. https:/www.manilatimes.net/2017/03/08/news/top-stories/house-approves-deathpenalty-bill/316049/ (accessed on 18/7/2020). The Pilipino government first abolished the death penalty (for all crimes) in 1987. But, they reintroduced it in 1999, directly contravening the United Nations' International Covenant on Civil and Political Rights (ICCPR), which it ratified in 1986. If this bill is approved by the Senate, the government will contravene the ICCPR (again) and the ICCPR's Second Optional Protocol, which it ratified in 2007; United Nations Human Rights Committee (2004). Pagdayawon Rolando v. The Philippines, CCPR/C/82/D/1110/2002, 8 December 2004. https://www.refworld.org/cases,HRC,421f00266.html (accessed on 18/7/2020); Joseph, S and Castan, M. (2013). The International Covenant on Civil and Political Rights. Oxford: Oxford University Press, 194; UN (2019b). 12. Second Optional Protocol to the International Covenant on Civil and Political Rights, aiming at the abolition of the death penalty. https://treaties.un.org/Pages/ViewDetails.aspx?src $=$ IND\&mtdsg_no $=$ IV-12\&chapter $=4 \&$ clang $=$ _en $($ accessed on 18/7/2020).

${ }^{11}$ East Asia: China, Japan, the Democratic People's Republic of Korea (DPRK), the Republic of Korea, and Taiwan.Southeast Asia: Brunei, Cambodia, Indonesia, Laos, Malaysia, Myanmar, the Philippines, Singapore, Thailand, Timor-Leste, and Vietnam.

${ }^{12}$ Amnesty International supra 7. These states are China, the DPRK, Indonesia, Japan, Malaysia, Singapore, Taiwan, Thailand, and Vietnam.

${ }^{13}$ Amnesty International (2016). Death Sentences and Executions 2016. Amnesty. https://www.amnesty.org/download/Documents/ACT5057402017ENGLISH.PDF (accessed on 20/7/2020). This article used data from 2016 because this is the most recent year that has (relatively) accurate data for the DPRK.

${ }^{14}$ Ibid. These figures include conservative estimates of the number of death penalties handed down in Iran, China and the DPRK. These estimates are based on information from: Amnesty International supra 13; The Dui Hua Foundation. (2019). Death Penalty Reform. https://duihua.org/resources/death-penalty-reform/ (accessed on 18/7/2020); Smith, E. (2016). Public executions on the rise in North Korea as Kim Jong Un worries about safety. https://www.upi.com/Top_News/WorldNews/2016/10/20/Public-executions-on-the-rise-in-North-Korea-as-Kim-Jong-Unworries-about-safety/5961476970354/ (accessed on 18/7/2020).

15 Amnesty International (2018). Death Sentences and Executions 2018. Amnesty. https://www.amnesty.org/download/Documents/ACT5098702019ENGLISH.PDF (accessed on 20/7/2020). 
areas are exceedingly important for any analysis of the death penalty. Currently (22/02/2020), five of the retentionist states in these areas have ratified, or acceded to, the United Nations' International Covenant on Civil and Political Rights (ICCPR), which makes it legally binding there. ${ }^{16}$ Accordingly, these states are legally obligated to restrict the scope of the death penalty, with the eventual aim of abolishing it. ${ }^{17}$ Out of these states, the Democratic People's Republic of Korea (DPRK) and Vietnam represent positive change, as they have restricted their lists of capital crimes from 33 to 5 and from 44 to 22, respectively. ${ }^{18}$ Conversely, Thailand and Japan represent negative change as they have expanded their lists of capital crimes to include corruption and organised crime, respectively. ${ }^{19}$ They have done so despite the apparent illegality of such expansion i.e. following the ratification of the ICCPR. Such changes seem to indicate that the

${ }^{16}$ UN. (2019a). 4. International Covenant on Civil and Political Rights. UNTC. https://treaties.un.org/Pages/ViewDetails.aspx?chapter $=4 \&$ clang $=$ en\&mtdsg_ no $=$ IV-4\&src $=$ IND $($ accessed on $18 / 7 / 2020)$. These states are The DPRK $(14$ September 1981), Indonesia (23 February 2006), Japan (21 June 1979), Thailand (29 October 1996), and Vietnam (24 Sep 1982). China signed the ICCPR on 5 Oct 1998, but it has not ratified it. Thus, it is not legally binding there. Malaysia, Singapore, and Taiwan have not signed, ratified, acceded, or succeeded to the ICCPR.

${ }^{17}$ Bae, S. (2009). South Korea's De Facto Abolition of the Death Penalty. Pacific Affairs, 82(3), 407-425, 408; The International Federation for Human Rights. (2008). The Death Penalty in Japan: The Law of Silence. https://www.fidh.org/IMG/pdf/ japon505a2008.pdf (accessed on 18/7/2020), 26; UNGA (1966). International Cove nant on Civil and Political Rights. United Nations, Treaty Series, vol. 999. https:// treaties.un.org/doc/Treaties/1976/03/19760323\%2006-17\%20AM/Ch_IV_04.pdf (ac cessed on 18/7/2020), 4.

${ }^{18}$ Hood, R and Hoyle, C. (2015). The Death Penalty: A Worldwide Perspective (4th Ed.) Oxford: Oxford University Press, 148-9; Cornell Law School (2020b). The Death Penalty in Vietnam. https://dpw.pointjupiter.co/country-search-post. cfm?country $=$ Vietnam (accessed on 18/7/2020). China has only signed the ICCPR, so it is not legally binding there. That said, it also seems to represent positive change, as it has reduced its list of capital crimes from 940 at the beginning of the 20th century to 55; Liang, B., Lu, H., and Hood, R. (2016). The Death Penalty in China: Policy, Practice, and Reform. Columbia University Press.

19 The International Federation for Human Rights supra 17 at 25; Amnesty International (2017). Death Sentences and Executions 2017. Amnesty. https://www. amnesty.org/download/Documents/ACT5079552018ENGLISH.PDF (accessed on 18/7/2020), 10. Consequently, 18 crimes there are eligible for capital punishment, including 9 crimes that do not result in the loss of life; Cornell Law School (2020a). The Death Penalty in Japan. https://dpw.pointjupiter.co/country-search-post. cfm? country = Japan (accessed on 18/7/2020). That said, in practice, capital punish ment appears to be reserved for those who commit homicide; The International Federation for Human Rights supra 17; Sato, M and Bacon, P. 
death penalty serves a (particularly) symbolic function in these states i.e. it validates public opinion there. This appears evidenced by the argument that political actors in retentionist states typically use to justify their state's retention: they cannot abolish the death penalty because it retains the support of the majority of the population there (the 'democratic' argument). Alternatively, some political actors argue that it should not be abolished in their state because it deters crime there (the 'deterrence' argument). Some other political actors combine these two arguments. Those who mainly (or solely) advocate the deterrence argument appear to attribute the following pragmatic function to the death penalty: it primarily deters crime e.g. via fear and/or anxiety. Here, it is worth noting that I take fear to mean an unpleasant emotional/cognitive future-oriented, long-term response broadly focused on a diffuse threat. ${ }^{20}$ I take anxiety to mean an unpleasant emotional/cognitive present-oriented, and short-term response to a clearly identifiable and specific threat. ${ }^{21}$ Those who mainly (or solely) advocate the democratic argument seem to attribute the following symbolic function to the death penalty: it primarily validates public opinion.

\section{ANALYSING EXECUTIONS}

In 2016, an estimated 3243 executions were carried out globally. ${ }^{22}$ At least 2228 of these $(68.70 \%)$ occurred in East and South-East Asia. ${ }^{23}$ Thus, it is difficult to overstate the importance of these sub-regions in any analysis of executions. In 2018, an estimated 2690 executions were carried out globally. At least 2,115 of these $(78.62 \%)$ occurred in East and South-East Asia. ${ }^{24}$

${ }^{20}$ VandenBos, G.R. (2015). APA Dictionary of Psychology (2nd Ed.) Washington, DC: American Psychological Association, 66, 413.

${ }^{21}$ Ibid.

22 Amnesty International supra 13 at 6 .

${ }^{23}$ Ibid. In 2016, executions occurred in (at least) China, Japan, Malaysia, the DPRK, Singapore, and Vietnam. These figures include conservative estimates of the number of executions that occurred in China, the DPRK, and Vietnam. These estimates are based on information from: The Dui Hua Foundation supra 14; Smith supra 14; La, H. (2017). https://vietnammoi.vn/hon-1000-truong-hop-bi-tuyen-tuhinh-trong-vong-ba-nam-19733.htm (accessed on 18/7/2020).

${ }^{24}$ Amnesty International supra 15. 
Globally, there appears to have been a general downward trend in executions in recent years. ${ }^{25}$ This trend also seems to pertain to East and Southeast Asia. ${ }^{26}$ However, the lack of reliable information on executions (in several states) in this area makes it exceedingly difficult to confirm this. ${ }^{27}$

According to the available data, there are vast discrepancies between the execution rates ( $x$ execution(s) per 1,000,000 of the population) of retentionist states in East and Southeast Asia. For instance, in 2016, Indonesia had an execution rate of 0.02 while the DPRK had an execution rate of 2.53. This discrepancy appears due to executions serving different functions in different states. These functions seem akin to the above-mentioned pragmatic and symbolic functions. ${ }^{28}$ To aid analysis, I have coded states with an execution rate greater than 1 execution per 1,000,0000 of the population as pragmatic and states with an execution rate below 0.5 executions per $1,000,000$ of the population as symbolic. ${ }^{29}$ In 2016 , China, the DPRK, and Vietnam had execution rates of $1.45,2.53$, and 1.57 , respectively. ${ }^{30}$ In 2018, China and Vietnam had execution rates of 1.44 and 0.89 . Thus, I have categorised China and the DPRK as pragmatic states. These states also appear characterised by high levels of secrecy. ${ }^{31}$ I take secrecy to mean one or more political actor(s)' intentionally withholding

${ }^{25}$ Amnesty International supra 19 at 6; Johnson, D.T. (2016). Retention and Reform in Japanese capital punishment. U. Mich. JL Reform, 49, 853, 855; Zimring, F.E, and Johnson, D.T. (2008). Law, society, and capital punishment in Asia. Punishment \& Society, 10(2), 103, 106.

${ }^{26}$ Zimring and Johnson supra 25 at 106; The Dui Hua Foundation supra 14. .

${ }^{27}$ Data on the use of the death penalty in China and Vietnam is classified as a state secret and little or no available information is typically available on Malaysia and the DPRK, due to restrictive state practices; Amnesty International supra 19 (2017).

${ }^{28}$ Zimring and Johnson supra 25 at 105.

${ }^{29}$ I decided to codify states based on their having an execution rate greater than 1 or less than 0.5 because a state's having an execution rate above 1 indicates that executions constitute an important part of that state's approach to crime while a state's having an execution rate below 0.5 does not.

${ }^{30}$ They executed at least 2000, 64, and 147 persons. Although Singapore's execution rate was 0.71 in 2016, it was 1.43 in 2017 and 2.31 in 2018. Thus, one could argue that it should also be placed in this category. However, due to the scope of this article, I shall omit further discussion of this point.

${ }^{31}$ Zimring, FE, Fagan, J, and Johnson, DT. (2010). Executions, Deterrence, and Homicide: a tale of two cities. Journal of Empirical Legal Studies, 7(1), 1, 10. 
information from one or more social actor(s). ${ }^{32}$ Such high levels of secrecy are presumably intended to instil higher levels of fear of, and/ or anxiety toward, governmental authority. ${ }^{33}$ This may or may not be intended to (indirectly) help deter crime ${ }^{34}$ and it may or may not do so. ${ }^{35}$ It could also problematise international scrutiny which may, in turn, heighten fear and/or anxiety, as the government then (at least) appears less susceptible to critique. Conversely, in 2016, Indonesia, Japan, Malaysia, Taiwan, and Thailand had execution rates of 0.02 , $0.02,0.29,0.04$, and 0.00 , respectively. ${ }^{36}$ These states had execution rates of $0.00,0.12,0.00,0.04$, and 0.01 in 2018. Thus, I have categorised them as symbolic states. Bar Japan and Thailand, these states also appear characterised by long-term downward trends in executions. ${ }^{37}$

Japan stands out within the above symbolic states because the secrecy and silence that "shroud" its executions is apparently "taken to extremes not seen in other nations." 38 This practice appears at odds with both the practices of other symbolic states and the symbolic function itself. ${ }^{39}$

\footnotetext{
${ }^{32}$ Scheppele, KL. (1988). Legal Secrets: Equality and efficiency in the common law. University of Chicago Press, 12.

${ }^{33}$ Botsman, D. (2005) Punishment and power in the making of modern Japan. Princeton, NJ: Princeton University Press, 33-35.

34 This is because there are many reasons why a government might intend to instil higher levels of fear of, and/or anxiety toward, governmental authority. Accordingly, the Japanese government's intentions behind doing so might not include (indirectly) deterring crime.

${ }^{35}$ Intuitively, such secrecy seems likely to deter crime i.e. have a positive effect on crime rates. That said, as this effect depends upon awareness of such secrecy, if there was a lack of awareness (at least on the part of would-be criminals) it could also have no effect on crime rates. Alternatively, such secrecy could have a negative effect on crime rates, as it undermines effective (and direct) deterrence by precluding much publicity; Johnson supra 2 at 106.

${ }^{36}$ They executed (at least) 0, 4, 4, 0, and 0 persons, respectively.

${ }^{37}$ Zimring and Johnson supra 25 at 106. As mentioned above, the data for Malaysia may be less reliable and/or conclusive than the data for the other states; ibid.

${ }^{38}$ Johnson supra 2 at 70 . This seems well evidenced by an interview between Oshima Reiko, a member of the Social Democratic Party (SDP), and Yoshida Tsukasa, the warden of the Nagoya Detention Centre, See Johnson supra 2 at 63-68 and the International Federation for Human Rights supra 17 at 43.

${ }^{39}$ Here, a critic may contend that a state may retain the death penalty for this symbolic function and still wish to keep the details of executions private. However, such secrecy entails the intentional withholding of information from the public (without their asking for, or consenting to, this). It seems unlikely that the public
} 
Japan's importance in discussions on the death penalty and/or executions appears derived from its being one of only two of the world's 25 "first world countries" 40 that retains (and uses) the death penalty for "ordinary" (i.e. not military) crimes. ${ }^{41}$ It is also one of only three of the world's 35 'liberal democracies' to do so. ${ }^{42}$ These factors make Japan an important place to test the limits of European human rights perspectives on non-neighbouring political environments. ${ }^{43}$ Induction from a detailed case study of Japan could also generate new insights about the circumstances of change in death penalty policy, executions and the practices surrounding both of them. ${ }^{44}$

Japan is the "most developed nation" in East and Southeast Asia and the only "first world country" in Asia that retains (and uses) the death penalty for ordinary crimes. ${ }^{45}$ The Japanese experience is important because it serves as both a potential counterexample to the general expectation that 'fully developed' democracies will abolish the death penalty and a potential leading indicator that other nations might also not abolish the death penalty as a rite of passage into 'full development. ${ }^{46}$ Thus, analysis of Japan might provide some insight into both the obstacles in the way of the abolition of the death penalty (and thus, executions) and the possible future trajectories of both executions and the death penalty in these sub-regions (and elsewhere). ${ }^{47}$

Footnote 39 continued would desire this. Therefore, it appears at odds with public opinion (and thus,) the symbolic function of executions.

${ }^{40}$ I.e. capitalist, industrialized countries within the Western European and United States (US)' sphere of influence; Nations Online. (2019). Countries of the First World. https://www.nationsonline.org/oneworld/first_world.htm (accessed on 18/7/ 2020).

${ }^{41}$ Nations Online supra 40. The US is the other retentionist first world country; ibid. Japan and the US are also the only two "developed democracies" that retain capital punishment and continue to carry out executions on a regular basis; Johnson supra 25 at 856 .

${ }^{42}$ McGill. (2019). Liberal democracy. https://www.cs.mcgill.ca/ rwest/wikispee dia/wpcd/wp/1/Liberal_democracy.htm (accessed on 18/7/2020); Zimring and John son supra 25 at 107 . India and the US are the other two; ibid.

${ }^{43}$ Zimring and Johnson supra 25 at 103-104.

44 Ibid, 104.

45 Zimring and Johnson supra 25 at 107; Nations Online supra 40.

${ }^{46}$ Zimring and Johnson supra 25 at 107.

${ }^{47}$ Ibid. 
In recent years, public sentiment in Japan has appeared strongly supportive of the death penalty and yet, executions have remained shrouded in secrecy and silence. ${ }^{48}$ Hence, this paper aims to answer the following research question: why are executions in Japan shrouded in secrecy and silence despite their apparent symbolic importance there?

Answering this question will enhance the academic literature on practices surrounding executions and the death penalty. ${ }^{49}$ To answer this question, this paper first contextualises the issue by outlining the history of executions in Japan. It then analyses the official justification for carrying out executions there: it would be undemocratic to discontinue them. Next, it briefly addresses the argument from deterrence i.e. executions are justified by their deterrent effect. Lastly, it critically analyses alternative explanations. This paper concludes that executions in Japan appear shrouded in secrecy and silence because those in power i.e. officials in the Japanese government assume that (1) this helps them maintain order and stability through fear and/or anxiety,, (2) the alternative (i.e. transparency) could encourage would-be offenders to game the system, and (3) the importance of order, stability and/or this concern (vis-à-vis would-be offenders) outweighs that of the symbolic importance of executions.

\section{HISTORICAL CHANGE}

Japan was not always a retentionist state and executions there were not always surrounded by secrecy and silence. ${ }^{50}$ In 810 AD, Japan became an abolitionist (de facto) state. ${ }^{51}$ The death penalty remained unused there until 1156 when it was brought back into use following

48 Johnson supra 2 at 70; Sato and Bacon (2015b). The Public Opinion Myth: Why Japan Retains the Death Penalty. The Death Penalty Project. https://www.death penaltyproject.org/knowledge/the-public-opinion-myth-why-japan-retains-thedeath-penalty/ (accessed on 18/7/2020), 15; Zimring and Johnson supra 25 at 107.

${ }^{49}$ It may also aid insight into the death penalty itself.

${ }^{50}$ Murano, K. (1990). Nihon no shikei (Japan's Death Penalty). Gendaijin bunsha, 40-41.

${ }^{51}$ The International Federation for Human Rights supra 17 at 6; Johnson supra 25 at 867 . Executions also ceased in November 1989 but they resumed in March 1993 and so Japan never (re)gained its abolitionist de facto status; Zimring and Johnson supra 25 at 107. 
the Hogen rebellion. It was then the "sanction of choice" throughout the Kamakura (1185-1333) and Edo (1603-1868) eras. ${ }^{52}$ Executions during these periods were "highly public affairs" intended to maximise deterrence and demonstrate (and celebrate) the "sovereignty" of the ruling authorities. ${ }^{53}$ For instance, at least 5000 Christians were publicly tortured and executed from $1614-1640 .^{54}$ The executions of Christians alone during this period gives Japan an execution rate of (at least) $13.23,{ }^{55}$ making it a (firmly) pragmatic state. Executions were carried out in myriad ways during these eras e.g. beheading, boiling, burning, crucifixion, and dismemberment ${ }^{56}$ Although the public was informed of laws and orders, they were apparently told little about punishments due to the Confucian concern that too much knowledge might encourage "the calculators.",57

In 1867, the Edo period ended and the nature of executions and the practices surrounding them changed. In 1882, hanging became the only way that the state could execute prisoners. ${ }^{58}$ It remains the sole means of execution in Japan. By 1882, public executions had been abandoned. Executions then had to be carried out on prison grounds, and only prison guards and (a select few) state officials were permitted to attend. ${ }^{59}$ Thus, "the principle of secrecy" was laid down in law. ${ }^{60}$ Executions can still only be carried out on prison grounds

52 Johnson supra 2 at 77.

${ }^{53}$ Johnson supra 2 at 77-78; Murano supra 48 at 41.

54 Johnson supra 2 at 78.

55 The estimated population of Japan in 1600 ranges from $10 \mathrm{mn}$ to $14 \mathrm{mn}$; Hayami, A. (2010). 6. Population Trends in Tokugawa Japan: 1600-1868. In Population, Family and Society in Pre-Modern Japan (pp. 99-112). Global Oriental, 99. I used an average of $14 \mathrm{mn}$ to ascertain the most conservative execution rate for this period. Precise estimates of executions remain debatable, but it seems likely that hundreds (if not thousands) of people were also executed (for different crimes) in this period.

${ }^{56}$ The International Federation for Human Rights supra 17 at 6; McNeil, D. (2008). Unmasking Capital Punishment: A Wave of Executions. https://apjjf.org/David-McNeill/2953/article.html (accessed on 18/7/2020); Murano supra 48 at 41.

${ }^{57}$ Johnson supra 2 at 78 . This reasoning may help explain Japan's use of secrecy regarding executions. More on this point in section IV.

${ }^{58}$ The International Federation for Human Rights supra 17 at 6; Johnson supra 2 at 79; McNeil supra 56.

59 Johnson supra 2 at 79.

${ }^{60} \mathrm{Ibid}$. 
and this "officials only" attendance policy remains in place (and unaltered). ${ }^{61}$ In terms of its execution rate, Japan remained pragmatic for several years after these changes. For instance, it executed (at least) 61, 52, 130, and 131 people in 1883, 1884, 1885, and 1886, respectively. ${ }^{62}$ Accordingly, its execution rates for these years were (at least) $1.65,1.37,3.43$, and 3.43. However, Japan's execution rate remained consistently below 1 after $1919 .{ }^{63}$ Ergo, executions seemingly came to serve an alternative function then. ${ }^{64}$

That said, the notion of executions coming to be used to primarily validate public opinion appears problematised by increasing levels of secrecy and silence surrounding executions since then (1919). For instance, during the US occupation (1945-1952), ${ }^{65}$ a censorship bureau comprised of (at least) 6,000 officials fostered a "pathology of selfcensorship," which appears to persist to this day. ${ }^{66}$ This pathology seemingly legitimised, and legitimises, prior secrecy and silence surrounding executions. It also facilitated, and facilitates, increasing levels of secrecy and silence. ${ }^{67}$ The use of censorship in this period also helped forge a political consciousness that, to this day, remains inclined to "acquiesce to overweening power," "conform to a dictated consensus," and "accept authority "fatalistically." 68 This political consciousness appears similarly conducive to secrecy and silence.

The practices surrounding executions in Japan also became increasingly secretive after US authorities left (most of) Japan in 1952. At that time, inmates on death row were notified at least one day in advance of their execution and allowed to meet their family

\footnotetext{
${ }^{61} \mathrm{Ibid}$.

${ }^{62}$ Amnesty International. (1983). The Death Penalty in Japan. Amnesty. https:// www.amnesty.org/download/Documents/200000/asa220021983en.pdf (accessed on $18 / 7 / 2020)$.

${ }^{63} \mathrm{Ibid}$.

${ }^{64}$ Japan's execution rate first dropped below 1 (to 0.96) in 1890. However, it then fluctuated above and below 1 in subsequent years; Ibid, 30 .

${ }^{65}$ This excludes Okinawa, which remained under US control until 1972.

${ }^{66}$ Johnson supra 2 at 86 . Japanese people were forbidden from discussing more than 60 topics during this period, including the abolition of the death penalty; ibid.

${ }^{67}$ The general lack of concern for criminals' human rights among the Japanese public seems to do likewise, as may the low salience of the issue among the public there; Johnson supra 25 at 870; Kawai, M. (2012). The Death Penalty in Japan. https://www.nippon.com/en/currents/d00025/the-death-penalty-in-japan.html (ac cessed on 18/7/2020); Sato and Bacon supra 48 at 40.

${ }^{68}$ Ibid.
} 
and friends, worship with other inmates, receive spiritual counselling, request last meals, and otherwise put their final affairs in order. ${ }^{69}$ These freedoms no longer exist. ${ }^{70}$ In 1963, the Ministry of Justice (MoJ) issued a "circular" declaring its authority to tighten restrictions on meetings, and correspondence, with death row inmates. ${ }^{71}$ During the rest of the 1960s, the Japanese state continued to strengthen controls on access to the condemned. ${ }^{72}$ Prosecutors in the $\mathrm{MoJ}$ also took away the discretion delegated to wardens to concentrate control into their own hands and reduce the number of "leaks" from corrections officials. ${ }^{73}$ Additionally, in 1975, inmates were banned from playing softball together and talking with inmates in adjacent cells. ${ }^{74}$ Viewings of the gallows have also been prohibited, visits to death row have been curtailed, and the Japanese government, prosecutors, and prison officials have apparently become increasingly unwilling to describe, explain, justify, or discuss such practices. ${ }^{75}$

Currently, correspondence with death row inmates is limited to authorized correspondents, and the letters that inmates send are usually censored i.e. a parts/parts of their content are erased or the letters go unsent. ${ }^{76}$ Strict limitations are also placed on the frequency, duration, and content of other forms of contact between the condemned and their lawyer(s) and close relatives. If one does not fall into one of these categories, contact is (apparently) almost impossible. ${ }^{77}$ Additionally, relatives of the condemned are only told of the execution after it has occurred and relatives of the victim are not told anything. ${ }^{78}$ Defence lawyers and the public also receive no prior

${ }^{69}$ Johnson supra 25 at 87; Johnson, D.T. (2006b). Where the state kills in secret: Capital punishment in Japan. Punishment \& Society, 8(3), 251, 261; Murano supra 50 at 15.

${ }^{70}$ The International Federation for Human Rights supra 17 at 43; Johnson supra 2 at 87; Johnson supra 69 at 261.

71 Johnson supra 2 at 92.

${ }^{72}$ Ibid.

${ }^{73}$ Ibid.

${ }^{74}$ Ibid, 87.

${ }^{75}$ Ibid, 68, 88. For prison officials, this may apparently be due to the risk of being punished for talking about the issue, See Oshima in Johnson supra 2 at 68.

${ }^{76}$ The International Federation for Human Rights supra 17 at 40. Although this openly flouts Japanese law, it is apparently common practice; ibid.

77 Johnson supra 2 at 73.

${ }^{78} \mathrm{Ibid}, 71$. 
notification. This practice appears oriented toward minimizing protests and limiting debate. ${ }^{79}$

Likewise, MoJ prosecutors select execution dates strategically e.g. when parliament is in recess and/or on a Thursday or Friday, that is, near the end of the "news week." 80 The MoJ also provides no explanation or justification for its selecting certain inmates for execution while allowing others to live. ${ }^{81}$ Furthermore, Ministers of Justice are appointed by the Prime Minister, who typically overlooks locally elected politicians for this role, apparently to prevent abolitionists from demonstrating in the Minister's home district. ${ }^{82}$ Moreover, the Cabinet appoints Supreme Court justices who, in turn, nominate tribunal and appeals court judges, and define their roles/ remuneration. ${ }^{83}$ This allows the government to effectively protect the shroud of secrecy and silence from the judiciary, at least in theory. It is also worth noting that Japanese prosecutors are accountable to the MoJ i.e. the government, not the judiciary. Critically, the government routinely denies (Japanese and foreign) scholars and reporters access to death penalty documents that, by law, should be made public. ${ }^{84}$ Additionally, no "private persons" i.e. journalists, relatives/friends of the condemned/victim, scholars, and members of the general public are allowed to witness executions. ${ }^{85}$ Only a public prosecutor, their assistant, the warden of the jail where the gallows is located, and members of the execution team are permitted to do so. ${ }^{86}$ The media and the public are also not permitted to view the gallows when it is

\footnotetext{
${ }^{79}$ Ibid.

${ }^{80} \mathrm{Ibid}, 73$. Senior MoJ officials have said that executions are no longer performed in between parliamentary sessions or during public/political holidays; The International Federation for Human Rights supra 17 at 4. Yet, all executions in 2018 took place between parliamentary sessions (and on either a Thursday or a Friday).

${ }^{81}$ Ibid, 74.

${ }^{82}$ Ibid.

${ }^{83}$ The International Federation for Human Rights supra 17 at 19; Johnson supra 25 at 878$)$.

${ }^{84}$ Johnson supra 2 at 75; The Government of Japan. (1948). Code of Criminal Procedure. http://www.japaneselawtranslation.go.jp/law/detail/?id $=3364 \& v \mathrm{vm}=$ $04 \&$ re $=02$ (accessed on 18/7/2020), article 53.

85 Johnson supra 2 at 72.

${ }^{86}$ The Death Penalty Project. (2013). The Death Penalty in Japan. https://www. deathpenaltyproject.org/knowledge/the-death-penalty-in-japan/ (accessed on 18/7/ 2020), 12; Johnson supra 2 at 72.
} 
not in use. ${ }^{87}$ These practices seemingly enforce secrecy and silence against both the public ${ }^{88}$ and the condemned. ${ }^{89}$

However, there seems to have been some 'progress' regarding Japan's shroud of secrecy and silence. For instance, in 2010, Chiba Keiko, then Minister of Justice, ${ }^{90}$ allowed "a handful of carefully chosen journalists from one of Japan's conservative press club[s] access to the gallows in Tokyo." "91 This was the first time in 50 years that reporters were allowed such access. ${ }^{92}$ Yet, the selection of specific journalists (over others) begs questions over how 'progressive' this act truly was, as "elite journalists" apparently collaborated with "elite bureaucrats" to "stage-manage" the story. ${ }^{93}$ Such scepticism also appears warranted regarding the death penalty study group, which was established under Chiba's orders. ${ }^{94}$ This is because this group met only eight times in its first 15 months, its meetings were closed to the public, and its discussions were apparently superficial and/or scripted/controlled by MoJ prosecutors. ${ }^{95}$ Other progressive

${ }^{87}$ Johnson supra 2 at 72 . There was one apparent exception to this rule in 2010. More on this in the paragraph below (in the main body).

${ }^{88}$ They do so directly i.e. by denying them access to the condemned, execution facilities, executions, and information about executions, and indirectly i.e. by denying such access to the families of the condemned/victims, lawyers, journalists, and scholars. Within this, directly enforced secrecy and silence constitutes an affront to public access i.e. they are measures which are intended to ensure that executions are kept out of the public eye. Their indirect counterparts constitute inhumane restrictions on access to the offender before execution.

${ }^{89}$ This distinction might aid research on secrecy vis-à-vis executions elsewhere.

${ }^{90}$ She served as the Minister of Justice for the Democratic Party of Japan (DPJ), which was in government from 2009 to 2012. Aside from this 3-year period and a brief interlude from 1993 to 1994, the (conservative) Liberal Democratic Party (LDP) has ruled Japan since 1955. It seemingly remains the most powerful political party in Japan.

${ }^{91}$ Johnson, D.T. (2013). Progress and problems in Japanese capital punishment. In Confronting Capital Punishment in Asia: Human Rights, Politics, and Public Opinion (pp. 168-184). Oxford University Press, 170; Johnson supra 25 at 866.

${ }^{92}$ McNeil supra 56 at 68 .

${ }^{93} \mathrm{Ibid}$.

${ }^{94}$ Such measures appear oriented toward improving public access (as conceptualised in footnote 83).

95 Johnson supra 91 at 170; Johnson supra 25, 866. Additionally, in 2009, Japan implemented a "lay judge" trial system in which laypersons adjudicate alongside professional judges in serious criminal cases. These trials typically consist of 6 layperson judges and three professional judges. Since this system was implemented, all murder defendants have been tried by "lay judge" tribunals; Johnson supra 25, 
measures appear similarly limited. For example, pieces of legislation that were passed in 2006 and 2007 assigned inspection boards to detention centres and brought some transparency to previously unwritten rules regarding visitation, respectively. ${ }^{96}$ Yet, these changes lacked publicity regarding their introduction and consequently, few have apparently benefitted from them. ${ }^{97}$ Only one change seems unaffected by such limitations: since 2007, the MoJ has announced the name of the executed person(s) in a press conference after their execution(s). ${ }^{98}$ That said, 'progress' in this area appears undermined by an apparent backsliding regarding information openness, as a new law took effect in 2004 which makes it a crime to use "records of criminal cases" for any purpose except the criminal trial. ${ }^{99}$ This restricts the flow of information to the public. Ergo, it is unclear whether the "shroud" surrounding executions in Japan is being (gradually) lifted or not. ${ }^{100}$

Footnote 95 continued

864. Initially, there was widespread hope that this system would make capital punishment more salient in society; Hirano, K. (2015). Public support for death penalty not overwhelming, researchers say. The Japan Times. https://www.japantimes.co.jp/ news/2015/09/16/national/public-support-death-penalty-not-overwhelming-re searchers-say/\#.XVvRKugzbIX (accessed on 18/7/2020); Johnson supra 25 at 880. Yet, progress in this area appears severely hampered by lay judges' being forbidden, by law, from disclosing information about their experiences at trial; Johnson supra 25 at 880 .

96 This change appears oriented toward the inhumane restrictions on access to the offender (as mentioned in footnote 103).

${ }^{97}$ The International Federation for Human Rights supra 17 at 10-11. The Japanese government also has yet to make all of the information concerning these reforms public; ibid, 11.

98 The International Federation for Human Rights supra 17 at 43; Sato and Bacon supra 48 at 34 . The MoJ previously notified news agencies that an execution(s) had occurred via fax, it did not reveal the names of the executed person(s); Johnson supra 2 at 71. This change appears oriented towards public access (as conceptualised in footnote 103).

99 Johnson supra 2 at 123 . This change appears to threaten public access accordingly.

${ }^{100}$ That said, even if Japan were to (entirely) cease these practices, it would still be worth studying the ways in which they have been used thus far i.e. to ascertain greater insight into why they ever existed and thus, why they exist (and may continue to do so) elsewhere. 


\section{SYMBOLISM AND DEMOCRACY}

Executions seem to serve a symbolic function in Japan i.e. they primarily validate public opinion. This appears evidenced by the "arguments from democracy," which remain the official justification for both retaining the death penalty and carrying out executions. ${ }^{101}$ Within this, many officials assert that the state should express "the will of the people" and as the majority of citizens support executions, it would be "anti-democratic" to discontinue them. Alternatively, some claim that discontinuing executions, despite public support for them, would undermine respect for the law. ${ }^{102}$ The validity of these arguments patently depends upon wide-spread public support for executions. To validate their arguments, defenders of the death penalty and/or executions in Japan i.e. numerous officials in the Japanese government, ${ }^{103}$ typically cite governmental surveys of the public.

These surveys have been conducted approximately every five years ${ }^{104}$ since 1956 and have (allegedly) consistently shown that the (vast) majority of the public supports capital punishment. ${ }^{105}$ They have also allegedly demonstrated that, with the exception of 2014, this support has increased over 20 years. ${ }^{106}$ For instance, this support was measured at $74 \%, 79 \%, 81 \%, 86 \%$, and $80.3 \%$ in 1994,1999 , 2004, 2009 and 2014, respectively. ${ }^{107}$

101 The International Federation for Human Rights supra 17 at 10; Johnson supra 2 at 118; Sato, M. (2013). The death penalty in Japan: Will the public tolerate abolition? Springer Science \& Business Media; Sato and Bacon supra 48 at 14-15.

102 Johnson supra 2 at 188; Sato and Bacon supra 48 at 15.

${ }^{103}$ Many other political actors also defend the death penalty in Japan. However, due to the scope of this essay, I shall omit further discussion of this point.

${ }^{104}$ Apparently, these surveys are typically conducted following the commission of a "particularly heinous" crime/crimes; The International Federation for Human Rights supra 17 at 7.

${ }^{105}$ Sato and Bacon supra 48 at 15.

106 Johnson supra 25 at 870 ; Sato supra 101 at 24-25. This increase appears partly due to three high-profile cases, and the defiant attitudes of their defendants: The AUM Shinrikyo cult's sarin attack on the Tokyo subway in 1995, Masumi Hayashi's poisoning of four people at a neighbourhood festival in Wakayama in 1998, and Takuma Mamoru's attack on Ikeda Elementary School in Osaka in 2001; Johnson supra 25 at $89-91$.

${ }^{107}$ Sato supra 101 at 25; The Japan Times (2016). Questioning capital punishment. https://www.japantimes.co.jp/opinion/2016/10/14/editorials/questioning-capital-pun ishment/ (accessed on 18/7/2020). 
That said, these surveys have long been subject to critique over their phrasing questions in a leading and (overly) simplistic manner i.e. in ways that are likely to increase/exaggerate support. ${ }^{108}$ The questions used in recent years remain vulnerable to this critique. ${ }^{109}$ For example, within these surveys, participants have been required to answer "Which of the following opinions concerning the death penalty do you agree with?"110 with "it should be abolished,"111 "it cannot be stopped"112 or "I don't know/I cannot choose."113 Numerous officials have (seemingly wilfully) (mis)interpreted participants' agreeing with "it cannot be stopped" as support for the death penalty. ${ }^{114}$ Additionally, the number of questions in the government's surveys has been reduced over time and the nature of these questions has been altered. This seems to evidence a shift away from an (at least somewhat genuine) exploration of public acceptance of abolition to a justification of retention. ${ }^{115}$

More open-ended surveys have convincingly undermined the extent and depth of support that is (allegedly) implied by the abovementioned governmental surveys. ${ }^{116}$ For instance, Sato and Bacon asked those who responded to the 2014 governmental survey to answer "Do you think that the death penalty should be kept as a form of criminal penalty or do you think it should be abolished?"117 with "it's definitely good that we have the death penalty," "11 "it should

\footnotetext{
108 Johnson supra 25 at 870; Sato supra 101 at 63.

${ }^{109}$ Sato supra 101 at 64.

110 shikeiseido nikanshite konoyouna ikenga arimasuga, anata ha dochirano ikenni sansei desuka in its original Japanese.

111 Originally Shikei ha haishi subeki dearu.

112 Originally shikei mo yamuwoenai.

113 Originally wakaranai/ichigaini ienai; Sato and Bacon supra 25 at 20.

${ }^{114}$ Sato and Bacon supra 48 at 24; Kawai supra 67.

${ }^{115}$ Sato and Bacon supra 48 at 22. It is also worth noting that those who took part in these surveys have also been shown to not be representative; Sato supra 101 at 68 70 .

116 Johnson supra 25 at 870; Sato supra 101 at 123-124, 128.

${ }^{117}$ Originally keibatsu toshite shikei ga atta hou ga ii to omoimasuka, soretomo haishi shitahouga iito omoimasuka.

118 Originally shikei ha zettaini atta houga ii.
} 
probably be kept,"119 "I don't know if it's good or bad,"120 “it should probably be abolished," 121 or "it should definitely be abolished." 122 These answers received $27 \%, 46 \%, 20 \%, 6 \%$, and $2 \%$ of the votes, respectively. ${ }^{123}$

Furthermore, current surveys solely concern themselves with the retention of the death penalty. They do not ask any questions about executions and/or the way executions are currently used. Hence, they cannot be used to (accurately) gauge public opinion on executions, in principle and/or in practice. They also cannot be used as (reliable) evidence of support for executions and/or the status quo.

That said, the majority of the Japanese public seems to support the retention of capital punishment. ${ }^{124}$ This challenges the following hypothesis regarding Japan's "shroud:" the state has insulated executions with secrecy and silence in reaction to a (democratic) threat to the death penalty. ${ }^{125}$ The notion that secrecy and silence remain in place to insulate executions from the threat of the abolitionist movement appears similarly unconvincing upon consideration of the movement's lack of both members and public support. ${ }^{126}$

Prima facie, these "arguments from democracy" may seemingly justify practices that enforce secrecy and silence against the condemned, as the Japanese public seems to favour harsh punishment and such practices may also aid executions' deterrent effect (if they were public knowledge). ${ }^{127}$ But, the use of secrecy and silence against

${ }^{119}$ Originally dochira ka toieba atta houga ii.

${ }^{120}$ Originally dochira tomo ienai. This could also seemingly account for those wishing to answer something along the lines of "I've never thought about it," "I don't know" and/or "I don't care.".

${ }^{121}$ Originally dochira ka toieba haishi subekida.

122 Originally shikei ha zettaini haishi subekida.

${ }^{123}$ Sato and Bacon supra 25 at 25.

${ }^{124}$ Johnson supra 25 at 870 ; Kawai supra 67 . However, it seems reasonable to assume that support for executions might be lower than support for the death penalty.

${ }^{125}$ Johnson supra 2 at 88, 91; Simmel, G. (1964). The Sociology of Georg Simmel. (Wolff, K., Trans). Simon and Schuster, 347.

${ }^{126}$ Johnson supra 2 at 92; Johnson supra 69 at 261, 264-4; Murano supra 48, 74 5.

127 The International Federation for Human Rights supra 17 at 17; Johnson supra 25 at 865; Sato supra 101 at 38. This deterrent effect is eminently debatable; Hood and Hoyle supra 17, 408-12; Gibbs, JP. (1986). Deterrence Theory and Research. In The Law as a Behavioral Instrument (pp. 87-131). University of Nebraska Press; Zimring, Fagan, and Johnson supra 28. More on this in the following section. 
the public appears patently at odds with democratic values and the symbolic function of executions. ${ }^{128}$ Within the "arguments from democracy," the first assertion i.e. it would be "anti-democratic" to discontinue executions because the majority of citizens support them, seems to provide no analytical leverage over why executions are shrouded in secrecy and silence in Japan. ${ }^{129}$ The validity of the second (less common) claim i.e. discontinuing executions despite public support would undermine respect for the law, appears undermined by consideration of any state that has discontinued executions and not seen this occur. ${ }^{130}$ However, the apparent desire to retain public respect for the law that underlies this claim may provide part of the answer to this essay's research question i.e. the state may believe that shrouding executions in secrecy and silence helps fulfil this desire.

\section{DETERRENCE}

Some officials in the Japanese government argue that the use of executions is justified by their deterrent effect. ${ }^{131}$ Additionally, much of the public apparently believes that executions deter homicide. ${ }^{132}$ This alleged deterrent effect is eminently debatable. ${ }^{133}$ As is the "brutalization" hypothesis i.e. executions facilitate violent crime by de-sensitizing society to violence. ${ }^{134}$ Here, I shall assume that even if this belief i.e. that executions deter crime, is grounded more in faith than fact, it is subjectively meaningful to its believers and therefore, it retains sociological significance. ${ }^{135}$ If executions were used primarily for deterrence, Japan would seemingly be a pragmatic state and thus,

\footnotetext{
${ }^{128}$ Johnson supra 2 at $117-119$.

${ }^{129}$ Here, a critic may contend that the public may support the death penalty without wanting executions to be public events. Be this as it may, the current government's use of secrecy i.e. its intentionally withholding information from the public (without their asking for, or consenting to, this) undermines the democratic (i.e. the official) justification for carrying out executions. .

130 That said, consideration of any state that has discontinued executions and seen this occur would seemingly do contrariwise.

${ }^{131}$ Johnson supra 2 at 120; Sato and Bacon supra 48 at 34. The government's surveys have also alluded to this argument by "consistently" asking whether participants believe the death penalty is a deterrent; Sato and Bacon supra 48 at 34 .

132 Johnson supra 25 at 887; Sato and Bacon supra 48 at 35.

133 Gibbs supra 127; Zimring, Fagan, and Johnson supra 28.

${ }^{134}$ Hood and Hoyle supra 17, 408-12.

135 Johnson supra 25 at 887.
} 
have a drastically different execution rate. The importance of this argument from deterrence appears further undermined by the enforcement of secrecy and silence (against the public) vis-à-vis executions since secrecy and silence undermine effective (and direct) deterrence. ${ }^{136}$ Executions may (or may not) serve a deterrent function, but the notion of their effectively (and directly) doing so in Japan appears implausible, as it lacks at least two of the requirements of an effective (direct) deterrent i.e. publicity and celerity. ${ }^{137}$ Ergo, the argument from deterrence appears dubious (at least regarding Japan) and cannot seemingly provide much (if any) analytical leverage over why executions in Japan remain shrouded in secrecy and silence.

\section{ALTERNATIVE EXPLANATIONS}

Some other officials in the Japanese government rationalise the shroud of secrecy and silence that surrounds executions in Japan by asserting that "secrecy is a Japanese tradition." 138 In doing so, they seemingly argue that executions should remain shrouded in secrecy and silence because it has been that way for a long time. However, the claim that it has been that way for a long time appears at odds with Japan's post-war history, as evidenced by the expansion of secrecy and silence vis-à-vis executions since then. ${ }^{139}$ Moreover, even if this claim were (shown to be) true, this argument would be logically fallacious, as it derives an 'ought' from an 'is. ${ }^{140}$

Alternatively, one may argue that this shroud stems from the above-mentioned "pathology of self-censorship" in Japan i.e. it represents conscious attempts to cultivate a favourable image of Japan, an (unconscious) habit, or both. ${ }^{141}$ Yet, these arguments appear critically undermined by consideration of the amount of international pressure that supra-national bodies and NGOs have put on the Ja-

136 The Japan Times supra 107; Johnson supra 2 at 120.

${ }^{137}$ Johnson supra 2 at 106 . In accordance with p. 4, it seems that such secrecy could potentially (indirectly) help deter crime. However, it would seemingly do so at the expense of effectively (and directly) deterring crime; ibid.

138 Ibid, 103.

139 Johnson supra 2 at 103.

140 Ibid.

${ }^{141}$ Ibid, 86. 
panese government over this issue and the amount of (negative) international press coverage that it has attracted over the years. ${ }^{142}$

That said, consideration of Japan's history might help explain why executions in Japan are shrouded in secrecy and silence. This shroud might remain in place due, in part, to the persistence of goals that stem from the Edo era. Within this era, harsh punishments were sought to attain order and stability through fear and/or anxiety. ${ }^{143}$ The secrecy and silence that currently surrounds executions in Japan appears somewhat oriented towards this goal, as it seems to augment fear and/or anxiety by increasing state power, directly and indirectly. ${ }^{144}$ It directly increases state power by increasing the informational asymmetry between the public and the state and the public's fear of, and/or anxiety towards, governmental authority. ${ }^{145}$ It indirectly increases state power by (1) conveying the message that "state killing is state business" 146 and (2) making the state less susceptible to critique, internationally and domestically. ${ }^{147}$ Domestically, this shroud may prevent the public from acting as an effective check on governmental power. This appears particularly problematic because Japan is one of only two liberal democracies that regularly carry out executions. ${ }^{148}$

The above-mentioned (Confucian) concern that too much knowledge can encourage "the calculators" may also help explain the use of secrecy (against the public) regarding executions. ${ }^{149}$ Further

${ }^{142}$ Bae supra 17 at 407; The International Federation for Human Rights supra 17 at 7, 27-8; Sato and Bacon supra 48 at 2-15.

${ }^{143}$ Lawson, C. (2015). 6. Reforming Japanese corrections: catalysts and conundrums. In Who Rules Japan?: Popular Participation in the Japanese Legal Process (pp. 128-163). Edward Elgar Publishing, 134; Murano supra 48 at 41.

144 This may or may not (indirectly) deter crime. It is worth noting that although crime may be deterred via fear and/or anxiety, fear/anxiety and deterrence are not the same thing. For instance, someone could become more likely to commit a crime in response to their state's (perceived or actual) overreach and executions may facilitate violent crime by de-sensitizing society to violence i.e. the brutalization hypothesis; Hood and Hoyle supra 17, 408-412. Alternatively, someone could become more afraid and/or anxious but no more deterred from crime.

${ }^{145}$ Botsman supra 32 at 33 .

146 Johnson supra 2 at 111.

${ }^{147}$ Johnson supra 25 at 879 . It may also do so by suppressing knowledge (more) generally; Flybjerg, B. (1998) Rationality and Power: Democracy in Practice. (Sampson, S., Trans). Chicago, IL: University of Chicago Press, 36.

148 Johnson supra 2 at 119 ; Johnson supra 25 at 856 . The US is the other; ibid.

149 Johnson supra 2 at 78. 
analysis of the justificatory role that this belief can play vis-à-vis Japan's "shroud" may provide insight into the practices of Japan and other secretive retentionist states that share elements of Confucian philosophy i.e. China and Vietnam. ${ }^{150}$ In sum, executions in Japan appear shrouded in secrecy and silence despite their symbolic importance because those in power i.e. officials in the Japanese government assume that 1) this helps them maintain order and stability through fear and/or anxiety and 2) the alternative (i.e. transparency) could encourage would-be offenders to game the system.

\section{CONCLUSION}

Japan is an important case study for research on practices that surround executions. Analysis of this case study aids insight into retentionist states, generally, and retentionist states that share elements of Confucian philosophy, specifically. Executions in Japan appear to serve a symbolic function i.e. they primarily validate public opinion. This appears evidenced by its low execution rate and the official justification for retaining the death penalty (and carrying out executions) i.e. abolishing the death penalty (and thus, executions) would be undemocratic. Yet, this justification appears undermined by the secrecy and silence that shroud executions in Japan, and it can offer little insight into why this shroud exists. As shown, "arguments from deterrence" fare (at least) as badly. Although arguments premised on Japanese tradition and/or a pathology of self-censorship offer some analytical leverage over this issue, they appear fundamentally flawed. Rather, executions in Japan appear shrouded in secrecy and silence despite their symbolic importance because those in power i.e. officials in the Japanese government assume that (1) this helps them maintain order and stability through fear and/or anxiety (2) the alternative (i.e. transparency) could encourage would-be offenders to game the system and (3) the importance of order, stability and/or this concern regarding the gaming of the system outweighs that of the symbolic importance of executions.

${ }^{150}$ Liu, J. (2009). Asian Criminology-Challenges, Opportunities, and Directions. Asian Journal of criminology, 4(1), 1, 4. 


\section{ACKNOWLEDGEMENTS}

I would like to take this opportunity to express my gratitude to Willem Visser 't Hooft for his support and to Steven E Holmes for his kindness, patience and insight. I could not have completed this work without their help.

Open Access This article is licensed under a Creative Commons Attribution 4.0 International License, which permits use, sharing, adaptation, distribution and reproduction in any medium or format, as long as you give appropriate credit to the original author(s) and the source, provide a link to the Creative Commons licence, and indicate if changes were made. The images or other third party material in this article are included in the article's Creative Commons licence, unless indicated otherwise in a credit line to the material. If material is not included in the article's Creative Commons licence and your intended use is not permitted by statutory regulation or exceeds the permitted use, you will need to obtain permission directly from the copyright holder. To view a copy of this licence, visit http:// creativecommons.org/licenses/by/4.0/.

Publisher's Note Springer Nature remains neutral with regard to jurisdictional claims in published maps and institutional affiliations. 